\title{
Diagnostic utility of biomarkers of left ventricular stress in patients with aortic stenosis and preserved left ventricular ejection fraction
}

\author{
Sebastian Sobczak ${ }^{1}$, Agata Sakowicz ${ }^{2}$, Tadeusz Pietrucha ${ }^{2}$, Malgorzata Lelonek ${ }^{1}$ \\ ${ }^{1}$ Department of Noninvasive Cardiology, Medical University of Lodz, Poland \\ ${ }^{2}$ Department of Medical Biotechnology, Medical University of Lodz, Poland
}

Kardiochirurgia i Torakochirurgia Polska 2017; 14 (2): 93-98

\begin{abstract}
Introduction: Aortic stenosis (AS) is the most common acquired valvular heart disease. The early identification of patients with severe AS is crucial. NT-proBNP is a well-known biomarker of pressure overload, and its role in patients with AS has been demonstrated in previous studies. Another, less well-known biomarker of pressure overload is SST2 protein, and its role in AS is unclear.

Aim: To evaluate the utility of SST2 protein, NT-proBNP and selected clinical parameters in the assessment of degenerative AS severity in a population with preserved left ventricular ejection fraction (LVEF).

Material and methods: Sixty-nine consecutive patients (mean age: $68.42 \pm 12.58$ years, $55.07 \%$ male) with symptomatic degenerative AS and preserved LVEF $\geq 45 \%$ were prospectively included. At enrollment complete transthoracic echocardiographic examination, ECG analysis, and standard laboratory tests including NT-proBNP were performed and blood samples for SST2 were obtained.

Results: There were 43 (62.32\%) patients with severe AS. The multivariate stepwise linear regression models revealed that only systolic blood pressure (SBP), Sokolow-Lyon index and left ventricular end-diastolic diameter (LVEDD) were independently associated with severe AS. Spearman correlation coefficients analysis showed no correlations between SST2 levels and a mild to moderate correlation between NT-proBNP concentration and parameters of AS severity. However, levels of NT-proBNP $(p=0.1857)$ and SST2 $(p=0.7851)$ did not differentiate patients according to severity of AS.

Conclusions: In the study population with degenerative AS and preserved LVEF neither the NT-proBNP nor SST2 concentrations can be used to differentiate patients according to the severity of AS.
\end{abstract}

Key words: aortic stenosis, biomarkers, NT-proBNP, sST2.

\section{Streszczenie}

Wstęp: Stenoza aortalna (SA) jest najczęstszą nabytą wadą serca. Wczesna identyfikacja pacjentów z ciężką SA jest bardzo ważna. NT-proBNP to dobrze znany biomarker przeciążenia ciśnieniowego i jego rola u pacjentów z SA została wykazana w poprzednich badaniach. Innym, mniej znanym biomarkerem przeciążenia ciśnieniowego jest białko sST2; jego rola w SA jest nieznana.

Cel: Ocena użyteczności białka sST2, NT-proBNP oraz wybranych parametrów klinicznych w ocenie zaawansowania zwyrodnieniowej SA w populacji z zachowaną funkcją skurczową lewej komory.

Materiał i metody: W badaniu wzięło udział 69 pacjentów (średni wiek: $68,42 \pm 12,58$ roku, 55,07\% mężczyzn) z objawową zwyrodnieniową SA i zachowaną funkcją skurczową lewej komory $\geq 45 \%$. Wykonano pełne przezklatkowe badanie echokardiograficzne, analizę EKG, standardowe badania laboratoryjne, $w$ tym stężenie NT-proBNP, oraz pobrano próbki krwi na oznaczenie SST2.

Wyniki: Pacjenci z ciężką SA stanowili 62,32\% $(n=43)$. Analiza wieloczynnikowa metodą regresji logistycznej krokowej wykazała, że jedynie skurczowe ciśnienie tętnicze, wskaźnik Sokolowa-Lyona oraz wymiar końcoworozkurczowy lewej komory były niezależnie powiązane z obecnością ciężkiej SA. Analiza korelacji rang Spearmana nie wykazała związku pomiędzy stężeniem SST2, natomiast wykazała małą do umiarkowanej korelację pomiędzy stężeniem NT-proBNP a parametrami zaawansowania SA. Ponadto stężenia NT-proBNP $(p=0,1857)$ i sST2 ( $p=0,7851)$ nie różnicują pacjentów ze względu na zaawansowanie SA.

Wnioski: Stężenia biomarkerów NT-proBNP i sST2 nie mogą zostać użyte do oceny zaawansowania SA u pacjentów z zachowaną funkcją skurczową lewej komory.

Słowa kluczowe: stenoza aortalna, biomarkery, NT-proBNP, sST2.

Address for correspondence: Prof. Malgorzata Lelonek MD, PhD, Department of Noninvasive Cardiology, Medical University of Lodz, 4 Kościuszki St, 90-418 Lodz, Poland, e-mail: malgorzata.lelonek@umed.lodz.pl Received: 10.09.2016, accepted: 11.04.2017. 


\section{Introduction}

Degenerative aortic stenosis (AS) is currently the most common acquired valvular heart disease (VHD), and the third cardiovascular disease in the population of developed countries. Due to the observed aging of society the incidence of AS will steadily grow. An important issue is the early identification of patients with severe AS before it leads to impaired left ventricular (LV) systolic function [1]. Aortic valve stenosis leads to increased LV afterload resulting in an increase in LV wall stretch and wall hypertrophy of the LV as a compensatory mechanism to pressure overload [2]. Pressure overload lead to synthesis and release of natriuretic peptides, markers of LV wall stress [3]. Previous studies have shown elevated concentration of $\mathrm{N}$-terminal pro-B-type natriuretic peptide (NT-proBNP) in both patients with non-severe and those with severe AS. Moreover, in patients with AS NT-proBNP correlates with functional status assessed with New York Heart Association (NYHA) functional class and independently correlates with postoperative outcomes irrespective of clinical and echocardiographic factors [4].

Another biomarker of LV biomechanical overload is SST2 protein. ST2 is an IL-1 receptor family member with two isoforms: transmembrane (ST2L) and soluble (SST2). Interleukin-33 (IL-33) is a functional ligand for ST2L and has a cardioprotective effect against myocardial hypertrophy, fibrosis and apoptosis [5]. sST2 reduces the favorable effect of IL-33 because it acts as a decoy receptor [6].

It has been demonstrated that SST2 protein is a valuable prognostic biomarker in patients with myocardial infarction (MI), acute heart failure (AHF) and chronic heart failure (CHF) [7-9]. However, the role of sST2 protein in patients with AS is still unclear.

\section{Aim \\ The aim of our study was to evaluate the utility of SST2 protein, NT-proBNP and selected clinical parameters in the assessment of degenerative AS severity in a population with preserved left ventricular ejection fraction (LVEF).}

\section{Material and methods}

Sixty-nine consecutive patients (mean age: $68.42 \pm 12.58$ years, $55.07 \%$ male) with degenerative AS and preserved LVEF $\geq 45 \%$ hospitalized in the Cardiology Department to assess the severity of AS were prospectively included. All were symptomatic and clinically stable for at least 4 weeks in NYHA functional class II to ambulatory IV. Subjects with a concomitant significant disease of another valve, acute heart failure, acute coronary syndrome, autoimmune diseases and other inflammatory states were excluded.

At the time of study entry detailed demographic and clinical data (age, gender, body mass index (BMI), comorbidities) were collected and twelve-lead ECG (heart rate, QRS duration, QTC duration, Sokolow-Lyon index) was performed. At hospital admission the following standard laboratory tests were performed: hemoglobin, white blood cells, neutrophils, platelets, sodium level, creatinine level, estimated glomerular filtration rate, blood urea nitrogen, glucose, total cholesterol, low-density lipoproteins, highdensity lipoproteins, triglycerides, high-sensitivity C-reactive protein (hs-CRP), high-sensitivity troponin T (hs-TnT) and NT-proBNP.

At enrollment patients also underwent a complete transthoracic echocardiographic examination (TTE) and the following data were obtained: left ventricular end-diastolic diameter (LVEDD), left ventricular end-systolic diameter (LVESD), end-diastolic interventricular septum thickness (IVSd), end-systolic interventricular septum thickness (IVSs), end-diastolic posterior wall thickness (PWd), and end-systolic posterior wall thickness (PWs). The LVEF was measured in the four- and two-chamber apical view by the Simpson method. Parameters of AS severity - maximum jet velocity, mean transvalvular pressure gradient and aortic valve area (AVA) (calculated by the continuity equation) - were measured using the Doppler method in TTE. All examinations were performed by experienced echocardiographers as recommended by the European Society of Echocardiography.

According to aortic valve area patients were divided into two subgroups: severe (AVA $\left.<1.0 \mathrm{~cm}^{2}\right)$ and non-severe AS (AVA $\geq 1.0 \mathrm{~cm}^{2}$ ).

At enrollment blood samples for SST2 were obtained by venipuncture and were collected into EDTA vacuum tubes. Immediately after collection the samples were centrifuged and we separated the plasma to a new Eppendorf tube. After separation the plasma was frozen at $-76^{\circ} \mathrm{C}$. Concentrations of SST2 were measured using sandwich monoclonal enzyme-linked immunosorbent assay kits (Medical and Biological Laboratories, no. 7638, MA, USA). The longest time of storage of the plasma at $-76^{\circ} \mathrm{C}$ was 12 month. All samples were measured in triplicate to assess the repeatability. The limit of detection (sensitivity) was $0.032 \mathrm{ng} / \mathrm{ml}$ and the upper limit was $4 \mathrm{ng} / \mathrm{ml}$. Measurements were carried out in the Department of Medical Biotechnology at the Medical University of Lodz.

The study conforms with the principles outlined in the Declaration of Helsinki and was approved by Bioethics Committee of the Medical University of Lodz. All subjects provided written informed consent.

\section{Statistical analysis}

Categorical variables were reported as the number of observations $(N)$ and the corresponding percentage (\%) and analyzed with the $\chi^{2}$ test or $\chi^{2}$ test with Yates' adjustment.

Normality of quantitative variables was tested using the Shapiro-Wilk test for normality. Because of the lack of normality for the majority of variables, they were presented as medians with interquartile range. Patients were divided into two subgroups: severe AS and non-severe AS. Differences between groups were analyzed using Student's $t$-test (normal distribution) or Mann-Whitney U-test (not normal distribution).

For significant quantitative variables receiver operating characteristic (ROC) curves were drawn and optimal deci- 
sion thresholds were found using the Youden index. Sensitivity, specificity, positive predictive value (PPV) and negative predictive value (NPV) were calculated. Odds ratios (OR) with $95 \%$ confidence interval $(\mathrm{Cl})$ were also presented.

Significant variables $(p<0.1)$ were analyzed using stepwise linear regression models. To assess correlations between SST2 and NT-proBNP with echocardiographic parameters of aortic stenosis severity, Spearman correlation coefficients were used. A $p$-value $<0.05$ was considered statistically significant.

Statistical calculations were performed with Statistica 10 PL (StatSoft Inc., USA) and SPSS v. 21 (SPSS Inc., USA) and R - project v. 3.0.2 (R Core Team, The R Foundation for Statistical Computing, Vienna, Austria).

\section{Results}

The baseline and echocardiographic characteristics of the total cohort and comparison between patients with se- vere and non-severe AS are shown in Tables I and II. There were 43 (62.32\%) patients with severe AS. Univariate stepwise linear regression analysis showed that systolic blood pressure (SBP), LVEDD, LVESD, QRS duration and SokolowLyon index were predictors of severe AS. The multivariate stepwise linear regression models revealed that only systolic blood pressure (SBP), Sokolow-Lyon index and LVEDD were independently associated with severe AS. Results of univariate and multivariate stepwise linear regression models are shown in Table III. Moreover, patients with severe AS had higher values of IVSd and PWd and had a higher incidence of diastolic dysfunction.

For variables that were significantly associated with the presence of severe AS, receiver operating characteristic (ROC) curves were drawn and optimal decision thresholds were found using the Youden index. Sensitivity, specificity, positive predictive value, and negative predictive value were calculated. Odds ratios (ORs) with 95\% confidence intervals

Tab. I. Baseline characteristics of total cohort and comparison between patients with severe aortic stenosis (AS) and non-severe AS. Variables are shown as median values with upper and lower quartiles

\begin{tabular}{|c|c|c|c|c|}
\hline Variables & $\begin{array}{l}\text { Total cohort } \\
\quad(n=69)\end{array}$ & $\begin{array}{l}\text { Severe AS } \\
(n=43)\end{array}$ & $\begin{array}{l}\text { Non-severe AS } \\
\quad(n=26)\end{array}$ & $P$-value \\
\hline Age [years] & $70(61-77)$ & $70(61-77)$ & $71.5(59-77)$ & 0.9802 \\
\hline Men, $n(\%)$ & $31(44.93)$ & & & \\
\hline BMI [kg/m²] & $27.9(25.1-31)$ & $27(24.7-29.9)$ & $29.7(26.1-31.1)$ & 0.2702 \\
\hline $\mathrm{SBP}[\mathrm{mm} \mathrm{Hg}]$ & $130(120-140)$ & $130(120-140)$ & $120(120-130)$ & 0.0174 \\
\hline $\mathrm{DBP}[\mathrm{mm} \mathrm{Hg}]$ & $70(70-80)$ & $70(70-80)$ & $75(60-80)$ & 0.5154 \\
\hline NYHA class & $3(2-3)$ & $3(2-3)$ & $2(2-3)$ & 0.0037 \\
\hline Heart rate $[\mathrm{bpm}]$ & $70(65-80)$ & $70(65-80)$ & $67.5(60-75)$ & 0.3119 \\
\hline QRS duration [ms] & $95.5(90-100)$ & $90(82-100)$ & $99(92-114)$ & 0.0095 \\
\hline QTc duration [ms] & $429.5(408.5-451.5)$ & $421(400-443)$ & $434(417-463)$ & 0.0674 \\
\hline Sokolow-Lyon index [mm] & $28(23-36)$ & $33(25-37)$ & $25(19-28)$ & 0.0132 \\
\hline $\mathrm{sST} 2[\mathrm{ng} / \mathrm{ml}]$ & $0.26(0.18-0.44)$ & $0.29(0.17-0.53)$ & $0.26(0.21-0.44)$ & 0.7851 \\
\hline NT-proBNP [pg/ml] & $584(244-1445)$ & $644(268.6-1837)$ & $571(145.2-1207.5)$ & 0.1857 \\
\hline $\mathrm{TC}[\mathrm{mmol} / \mathrm{l}]$ & $4.8(4.1-5.5)$ & $4.6(4.1-5.3)$ & $4.95(3.6-5.6)$ & 0.9285 \\
\hline LDL [mmol/l] & $2.5(2.2-3.6)$ & $2.5(2.3-3.4)$ & $2.75(1.8-3.7)$ & 0.8434 \\
\hline $\mathrm{HDL}[\mathrm{mmol} / \mathrm{l}]$ & $1.31(1.1-1.59)$ & $1.29(1.12-1.42)$ & $1.38(1.03-1.7)$ & 0.6538 \\
\hline TG [mmol/l] & $1.32(0.9-1.58)$ & $1.3(1.06-1.58)$ & $1.32(0.74-1.48)$ & 0.5904 \\
\hline Glucose $[\mathrm{mmol} / \mathrm{l}]$ & $5.9(5.4-6.5)$ & $5.95(5.4-6.9)$ & $5.8(5.3-6.4)$ & 0.3667 \\
\hline BUN [mg/dl] & $6(4.9-7.4)$ & $5.7(4.7-7.25)$ & $6.6(5.3-7.8)$ & 0.2379 \\
\hline Creatinine $[\mu \mathrm{mol} / \mathrm{l}]$ & $76.5(67-84)$ & $75.5(67-84)$ & $77.5(67-90)$ & 0.1240 \\
\hline Bilirubin $[\mu \mathrm{mol} / /]$ & $11.45(7.2-15.4)$ & $9.2(6-15.4)$ & $13.6(8.6-15.4)$ & 0.4570 \\
\hline Uric acid $[\mu \mathrm{mol} / \mathrm{l}]$ & $341.5(303-400)$ & 331 (299-385) & $381(322-415)$ & 0.1921 \\
\hline $\mathrm{Hs}-\mathrm{CRP}[\mathrm{mg} / \mathrm{dl}]$ & $1.6(0.8-3.7)$ & $1.6(0.6-2.9)$ & $2.55(0.9-7.6)$ & 0.0459 \\
\hline Sodium [mmol/l] & 139 (138-141) & $139(138-141)$ & 139 (138-141) & 0.5362 \\
\hline $\mathrm{WBC}\left[10^{3} / \mu \mathrm{l}\right]$ & $7(6.3-8.3)$ & $7.1(5.8-8.6)$ & $6.8(6.4-8.3)$ & 0.8655 \\
\hline Hemoglobin [g/dl] & $14.23(12.88-15.5)$ & $13.8(12.6-15.44)$ & $14.84(13.2-15.68)$ & 0.1507 \\
\hline Platelets $\left[10^{3} / \mu \mathrm{l}\right]$ & 206 (174-255) & $208(167-264)$ & 202 (184-252) & 0.9951 \\
\hline Neutrophils (\%) & $61(55-66.6)$ & $64.3(56-67)$ & $57.6(54.6-63)$ & 0.0807 \\
\hline
\end{tabular}

$\mathrm{BMI}$ - body mass index, BUN - blood urea nitrogen, DBP - diastolic blood pressure, HDL - high-density lipoprotein, HF - heart failure, hs-CRP - high-sensitivity C-reactive protein, hs-TnT - high-sensitivity troponin T, NT-proBNP - N-terminal pro-B- type natriuretic peptide, NYHA - New York Heart Association, SBP - systolic blood pressure, SST2 - soluble ST2, TC - total cholesterol, TG - triglycerides, WBC - white blood cells. 
Tab. II. Echocardiographic characteristics of total cohort and comparison between patients with severe aortic stenosis (AS) and nonsevere AS. Variables are shown as median values with upper and lower quartiles

\begin{tabular}{lcccc} 
Variables & $\begin{array}{c}\text { Total cohort } \\
(n=69)\end{array}$ & $\begin{array}{c}\text { Severe AS } \\
(n=43)\end{array}$ & $\begin{array}{c}\text { Non-severe AS } \\
(n=26)\end{array}$ & $P$-value \\
AVA $\left[\mathrm{cm}^{2}\right]$ & $0.8(0.6-1.3)$ & $0.7(0.53-0.8)$ & $1.4(1.25-1.68)$ & $<0.0001$ \\
\hline MPG $[\mathrm{mm} \mathrm{Hg}]$ & $42(24-50)$ & $45(42-56)$ & $20(13-28)$ & $<0.0001$ \\
\hline Peak aortic velocity [m/s] & $4.1(3.27-4.6)$ & $4.45(4.2-5.12)$ & $3(2.5-3.5)$ & $<0.0001$ \\
\hline LVESD $[\mathrm{cm}]$ & $3.1(2.8-3.6)$ & $3(2.8-3.3)$ & $3.6(3.05-3.95)$ & 0.0152 \\
\hline LVEDD $[\mathrm{cm}]$ & $4.8(4.5-5.3)$ & $4.8(4.4-5.1)$ & $5.1(4.7-5.7)$ & 0.0126 \\
\hline LVEF $(\%)$ & $61(57-65)$ & $62(58-66)$ & $59(51.5-62.5)$ & 0.0003 \\
\hline IVSd [cm] & $1.3(1.2-1.4)$ & $1.3(1.3-1.4)$ & $1.2(1-1.35)$ & 0.0290 \\
\hline IVSs $[\mathrm{cm}]$ & $1.7(1.6-1.9)$ & $1.8(1.65-1.9)$ & $1.7(1.5-1.9)$ & 0.3642 \\
\hline PWd $[\mathrm{cm}]$ & $1.2(1.1-1.3)$ & $1.25(1.2-1.3)$ & $1.05(1-1.13)$ & 0.0004 \\
\hline PWs $[\mathrm{cm}]$ & $1.7(1.6-1.8)$ & $1.7(1.6-1.8)$ & $1.6(1.4-1.8)$ & 0.2909 \\
\hline Diastolic dysfunction, $n(\%)$ & $32(46.38)$ & $25(58.14)$ & $7(26.92)$ & 0.0545 \\
\hline
\end{tabular}

Diastolic dysfunction includes impaired relaxation, pseudo-normal filling, and restrictive filling, and was assessed according to transmitral inflow pattern

(E/A ratio, deceleration time) or pulsed-wave TDI mean e' velocity. AVA - aortic valve area, IVSd - interventricular septal end-diastole, IVSs - interventricular septal end-systole, LVEDD - left ventricular end-diastolic diameter, LVEF - left ventricular ejection fraction, LVESD - left ventricular end-systolic diameter, MPG - mean pressure gradient, PWd - posterior wall end-diastole, PWs - posterior wall end-systole.

Tab. III. Univariate and multivariate stepwise linear regression analysis for the prediction of severe aortic stenosis

\begin{tabular}{lcccc} 
Variables & \multicolumn{2}{c}{ Univariate analysis } & \multicolumn{2}{c}{ Multivariate analysis } \\
\cline { 2 - 5 } SBP $[\mathrm{mm} \mathrm{Hg}]$ & OR $(95 \% \mathrm{Cl})$ & P-value & OR $(95 \% \mathrm{Cl})$ & $P$-value \\
\hline QRS duration $[\mathrm{ms}]$ & $1.047(1.006-1.089)$ & 0.023 & $1.081(1.001-1.168)$ & 0.015 \\
\hline Sokolow-Lyon index $[\mathrm{mm}]$ & $0.971(0.944-1.000)$ & 0.047 & $0.964(0.907-1.026)$ & 0.332 \\
\hline LVESD $[\mathrm{cm}]$ & $1.082(1.014-1.154)$ & 0.018 & $1.106(0.981-1.247)$ & 0.043 \\
\hline LVEDD $[\mathrm{cm}]$ & $0.358(0.131-0.975)$ & 0.045 & $1.143(0.126-10.376)$ & 0.817 \\
\hline Neutrophils $(\%)$ & $0.289(0.102-0.823)$ & 0.020 & $0.108(0.008-1.462)$ & 0.042 \\
\hline
\end{tabular}

LVEDD - left ventricular end-diastolic diameter, LVESD - left ventricular end-systolic diameter, SBP - systolic blood pressure.

Tab. IV. Results of receiver operating characteristic (ROC) curve analyses of significant variables for predicting severe aortic stenosis

\begin{tabular}{|c|c|c|c|c|c|c|c|}
\hline Variables & Cut-off point & AUC $(95 \% \mathrm{Cl})$ & Sensitivity (\%) & Specificity (\%) & PPV (\%) & NPV (\%) & OR $(95 \% \mathrm{Cl})$ \\
\hline $\mathrm{SBP}[\mathrm{mm} \mathrm{Hg}]$ & $\geq 132.5$ & $\begin{array}{c}0.665(0.534-0.797) \\
p=0.022\end{array}$ & 44.2 & 84.6 & 82.6 & 47.8 & $\begin{array}{c}4.354(1.281-14.802) \\
p=0.0139\end{array}$ \\
\hline LVEDD [cm] & $\leq 5.35$ & $\begin{array}{c}0.698(0.532-0.863) \\
p=0.022\end{array}$ & 90.0 & 41.2 & 78.3 & 63.6 & $\begin{array}{c}6.300(1.532-25.914) \\
p=0.0064\end{array}$ \\
\hline $\begin{array}{l}\text { Sokolow-Lyon } \\
\text { Index [mm] }\end{array}$ & $\geq 30.5$ & $\begin{array}{c}0.697(0.560-0.835) \\
p=0.008\end{array}$ & 58.5 & 80.0 & 82.8 & 54.1 & $\begin{array}{c}5.647(1.770-18.020) \\
p=0.0022\end{array}$ \\
\hline
\end{tabular}

AUC - area under the curve, $\mathrm{Cl}$ - confidence interval, HR - heart rate, LVEDD - left ventricular end-diastolic diameter, OR - odds ratio, PPV - positive predictive value, SBP - systolic blood pressure.

Tab. V. Spearman rank order correlations between SST2 and NT-proBNP levels and parameters of aortic stenosis severity

\begin{tabular}{lcccc} 
Parameters & \multicolumn{2}{c}{ SST2 } & \multicolumn{2}{c}{ NT-proBNP } \\
\cline { 2 - 5 } of AS severity & $R$ & $P$-value & $R$ & $P$-value \\
AVA & 0.0002 & 0.9986 & -0.3462 & 0.0096 \\
\hline MPG & -0.0555 & 0.6579 & 0.2621 & 0.0413 \\
\hline Peak aortic velocity & -0.0092 & 0.9432 & 0.2665 & 0.0413 \\
\hline
\end{tabular}

AS - aortic stenosis, AVA - aortic valve area, MPG - mean pressure gradient. 
(Cls) were also presented (Tab. IV). Spearman correlation coefficients analysis showed no correlations between SST2 levels and a mild to moderate correlation between NT-proBNP concentration and parameters of AS severity (Tab. V). Moreover, levels of NT-proBNP $(p=0.1857)$ and sST2 $(p=0.7851)$ did not differentiate patients according to severity of AS.

\section{Discussion}

Our study showed that in the study population with degenerative AS and preserved LVEF the concentrations of the biomarkers NT-proBNP and SST2 cannot be used to differentiate patients according to the severity of this valvular heart disease. In the available literature there are no studies evaluating the diagnostic value of both biomarkers in patients with AS and preserved LVEF.

Sawada et al. revealed that the II-33/ST2 system may be involved in the pathophysiology of AS [10]. They observed that IL-33 and SST2 were expressed in human aortic valves in patients with stenosis as well as regurgitation, there were no differences in expression levels of II-33, but SST2 expression levels were up-regulated in the group with AS [10]. Moreover, Bartunek et al. reported that serum SST2 levels were significantly higher in patients with AS compared to the healthy control group. However, they postulated that SST2 is not produced mainly in the myocardium, but vascular endothelial cells are the major source of increased SST2 and increased left ventricular end-diastolic pressure is a predominant hemodynamic factor of SST2 production [11]. Lancellotti et al. demonstrated in patients with AS and preserved LVEF that SST2 levels were related to left atrial size, LV hypertrophy, severity of AS and LV systolic function. Investigators revealed that SST2 protein is also a good prognostic marker in AS. In symptomatic patients it was correlated with symptomatic status assessed using NYHA functional class, while in asymptomatic patients SST2 was predictive of symptom-free survival, development of symptoms and aortic valve replacement (AVR) [12]. Predictive value of SST2 protein was confirmed in a study of 345 patients with severe AS treated invasively: surgical AVR or transcatheter AVR. SST2 was associated with outcome in both groups; there was 1.7-fold higher risk of postoperative mortality in patients with elevated levels of sST2 $p$ < 0.001). Moreover, a multiple biomarker approach including SST2, NT-proBNP and growth differentiation factor 15 (GDF-15) improved risk stratification in comparison to the Society of Thoracic Surgeons (STS) risk score alone [13].

In our study in patients with AS and preserved LVEF we established a correlation between NT-proBNP levels and parameters of AS severity: maximum jet velocity, mean transvalvular pressure gradient and AVA (Tab. V). Our results are consistent with previous reports [14, 15]. Despite the correlation with parameters of AS severity, in our research NT-proBNP did not differentiate patients according to AS severity: severe vs. non-severe AS. NT-proBNP is also a recognized predictor of cardiovascular events and perioperative risk in a population with aortic stenosis $[4,15]$, which was reflected in the current guidelines of the Euro- pean Society of Cardiology on the management of valvular heart disease [1].

Bartunek et al. showed that SST2 and NT-proBNP levels correlate with diastolic load (left ventricular end-diastolic pressure) irrespective of left ventricular systolic function [11]. In our study, patients with severe AS had significantly higher values of parameters of left ventricular hypertrophy (IVSd, PWd), but there was no significant difference in occurrence of diastolic dysfunction between the population with severe and non-severe AS $(p=0.0545)$. Probably the lack of statistical significance in occurrence of diastolic dysfunction is caused by the relatively small study population. This may explain the lack of difference in the concentration of tested biomarkers.

In our study Sokolow-Lyon index $\geq 30.5 \mathrm{~mm}, \mathrm{SBP} \geq$ $132.5 \mathrm{~mm} \mathrm{Hg}$ and LVEDD $\leq 5.35 \mathrm{~cm}$ were independently associated with severe AS. The Sokolow-Lyon index is a recognized prognostic factor for the presence of cardiac hypertrophy, regardless of etiology, including left ventricular hypertrophy $(\mathrm{LVH})$ in patients with AS [16]. However, ECG criteria of LVH including the Sokolow-Lyon index do not correlate well with echocardiographic parameters of LVH [17, 18]. The Sokolow-Lyon index value lower than $35 \mathrm{~mm}$ as a predictor of severe AS obtained in our study may be the outcome of "the relative voltage deficit" hypothesis, a deviation connected with changes in electrical features of the myocardium in LVH [19]. In the non-severe AS population, the Sokolow-Lyon index was demonstrated to be a risk factor of cardiovascular mortality and morbidity independent of other clinical and echocardiographic variables [20]. We hypothesize that assessment of the Sokolow-Lyon index in the resting ECG could be a low-cost and widely available screening tool for severe AS, mainly in asymptomatic and oligosymptomatic patients.

In our study there was a significant association between SBP with a cut-off point $\geq 132.5 \mathrm{~mm} \mathrm{Hg}$ and presence of severe AS. High prevalence of $30-40 \%$ of the concomitant hypertension in patients with AS has been described previously [21]. Moreover, in patients with AS and preserved LVEF, systolic hypertension and increased pulse pressure (defined as SBP-DBP) suggest that the degenerative process is not limited to the aortic valve, but also involves the vascular system distal to the valve [22].

In the studied population LVEDD $\leq 5.35 \mathrm{~cm}$ was independently associated with severe AS. According to LaPlace's law, LV pressure overload in AS leads to LV hypertrophy to maintain LV systolic function followed by adverse cardiac remodeling and impaired systolic function [23]. We included patients with preserved LVEF, which reflects the population before the occurrence of maladaptive cardiac remodeling. In the literature, there are reports of smaller LV cavities in patients with different pathophysiological forms of AS: patients without LV hypertrophy [24] and paradoxical low-flow, low-gradient severe AS [25]. However, further studies are needed to elucidate these issues.

This study has several limitations. This is a single-center study, and the number of patients in the study was rela- 
tively small. We assessed LVH only with the Sokolow-Lyon index; other algorithms including the Cornel voltage index and the Romhilt-Estes method were not used. We studied only patients with preserved LVEF, so the results could not be extrapolated to the population with reduced LVEF. We assessed only parameters of left ventricle wall thickness, without estimation of left ventricular mass.

\section{Conclusions}

In the study population with degenerative AS and preserved left ventricular systolic function the concentrations of the biomarkers NT-proBNP and SST2 cannot be used to differentiate patients according to the severity of this valvular heart disease despite the correlation of NT-proBNP levels with parameters of AS severity.

\section{Acknowledgments}

This study was supported by a Medical University of Lodz grant (502-03/1-005-02/502-14-186) to Sebastian Sobczak.

\section{Disclosure}

Authors report no conflict of interest.

\section{References}

1. Joint Task Force ont he Management of Valvular Heart Disease of the European Society of Cardiology (ESC) and the European Association for CardioThoracic Surgery (EACTS). Vahanian A, Alfieri O, Andreotti F, Antunes MJ, Barón-Esquivias G, Baumgartner H, Borger MA, Carrel TP, De Bonis M, Evangelista A, Falk V, lung B, Lancellotti P, Pierard L, Price S, Schäfers HJ, Schuler G, Stepinska J, Swedberg K, Takkenberg J, Von Oppell UO, Windecker S, Zamorano JL, Zembala M. Guidelines on the management of valvular heart disease (version 2012). Eur Heart J 2012; 33: 2451-2496.

2. Carabello BA. Introduction to aortic stenosis. Circ Res 2013; 113: 179-185.

3. Thygesen K, Mair J, Mueller C, Huber KM, Plebani M, Hasin Y, Biasucci LM, Giannitsis E, Lindahl B, Koenig W, Tubaro M, Collinson P, Katus H, Galvani M, Venge P, Alpert JS, Hamm C, Jaffe AS; Study Group on Biomarkers in Cardiology of the ESC Working Group on Acute Cardiac Care. Recommendations for the use of natriuretic peptides in acute cardiac care: a position statement from the Study Group on Biomarkers in Cardiology of the ESC Working Group on Acute Cardiac Care. Eur Heart J 2012; 33: 2001-2006.

4. Bergler Klein J, Klaar U, Heger M, Rosenhek R, Mundigler G, Gabriel H, Binder T, Pacher R, Maurer G, Baumgartner H. Natriuretic peptides predict symptom-free survival and postoperative outcome in severe aortic stenosis. Circulation 2004; 109: 2302-2308.

5. Sanada S, Hakuno D, Higgins LJ, Schreiter ER, McKenzie AN, Lee RT. IL-33 and ST2 comprise a critical biomechanically induced and cardioprotective signaling system. J Clin Invest 2007; 117: 1538-1549.

6. Mueller T, Dieplinger B. The Presage ST2 Assay: analytical considerations and clinical applications for high-sensitivity assay for measurement of soluble ST2. Expert Rev Mol Diagn 2013; 13: 13-30.

7. Shimpo M, Morrow DA, Weinberg EO, Sabatine MS, Murphy SA, Antman EM, Lee RT. Serum levels of the interleukin-1 receptor family member ST2 predict mortality and clinical outcome in acute myocardial infarction. Circulation 2004; 109: 2186-2190.

8. Januzzi JL, Peacock WF, Maisel AS, Chae CU, Jesse RL, Baggish AL, O’Donoghue M, Sakhuja R, Chen AA, van Kimmenade RR, Lewandrowski KB, LloydJones DM, Wu AH. Measurement of the interleukin family member ST2 in patients with acute dyspnea: results from the PRIDE (Pro-Brain Natriuretic
Peptide Investigation of Dyspnea in the Emergency Department) study. J Am Coll Cardiol 2007; 50: 607-613.

9. Sobczak S, Wojtczak-Soska K, Ciurus T, Sakowicz A, Pietrucha T, Lelonek M. Single sST2 protein measurement predicts adverse outcomes at 1-year follow-up in patients with chronic heart failure. Pol Arch Med Wewn 2014; 124: $452-458$.

10. Sawada H, Naito Y, Hirotani S, Akahori H, Iwasaku T, Okuhara Y, Miki K, Eguchi A, Mitsuno M, Miyamoto Y, Ohyanagi M, Tsujino T, Masuyama T. Expression of interleukin-33 and ST2 in nonrheumatic aortic valve stenosis. Int J Cardiol 2013; 168: 529-531.

11. Bartunek J, Delrue L, Van Durme F, Muller O, Casselman F, De Wiest B, Croes R, Verstreken S, Goethals M, de Raedt H, Sarma J, Joseph L, Vanderheyden $M$, Weinberg EO. Nonmyocardial production of ST2 protein in human hypertrophy and failure is related to diastolic load. J Am Coll Cardiol 2008; 52: 2166-2174.

12. Lancellotti P, Dulgheru R, Magne J, Henri C, Servais L, Bouznad N, Ancion A, Martinez C, Davin L, Le Goff C, Nchimi A, Piérard L, Oury C. Elevated plasma soluble ST2 is associated with heart failure symptoms and outcome in aortic stenosis. PLoS One 2015; 10: e0138940.

13. Lindman BR, Breyley JG, Schilling JD, Vatterott AM, Zajarias A, Maniar HS, Damiano RJ Jr, Moon MR, Lawton JS, Gage BF, Sintek MA, Aquino A, Holley CL, Patel NM, Lawler C, Lasala JM, Novak E. Prognostic utility of novel biomarkers of cardiovascular stress in patients with aortic stenosis undergoing valve replacement. Heart 2015; 101: 1382-1388.

14. Gerber IL, Stewart RA, Legget ME, West TM, French RL, Sutton TM, Yandle TG, French JK, Richards AM, White HD. Increased plasma natriuretic peptide levels reflect symptom onset in aortic stenosis. Circulation 2003; 107: 1884-1890.

15. Weber M, Arnold R, Rau M, Brandt R, Berkovitsch A, Mitrovic V, Hamm C. Relation of $\mathrm{N}$-terminal pro-B-type natriuretic peptide to severity of valvular aortic stenosis. Am J Cardiol 2004; 94: 740-745.

16. Beladan CC, Popescu BA, Calin A, Rosca M, Matei F, Gurzun MM, Popara AV, Curea F, Ginghina C. Correlation between global longitudinal strain and QRS voltage on electrocardiogram in patients with left ventricular hypertrophy. Echocardiography 2014; 31: 325-334.

17. Bacharova L; American Heart Association. What is recommended and what remains open in the American Heart Association recommendations for the standardization and interpretation of the electrocardiogram. Part V: electrocardiogram changes associated with cardiac chamber hypertrophy. J Electrocardiol 2009; 42: 388-391.

18. Sjöberg S, Sundh F, Schlegel T, Maynard C, Rück A, Wagner G, Ugander M. The relationship between electrocardiographic left ventricular hypertrophy criteria and echocardiographic mass in patients undergoing transcatheter aortic valve replacement. J Electrocardiol 2015; 48: 630-636.

19. Bacharova L. Electrical and structural remodeling in left ventricular hypertrophy - a substrate for a decrease in QRS voltage? Ann Noninvasive Electrocardiol 2007; 12: 260-273.

20. Greve AM, Boman K, Gohlke-Baerwolf C, Kesäniemi YA, Nienaber C, Ray S, Egstrup K, Rossebø AB, Devereux RB, Køber L, Willenheimer R, Wachtell K. Clinical implications of electrocardiographic left ventricular strain and hypertrophy in asymptomatic patients with aortic stenosis: the Simvastatin and Ezetimibe in Aortic Stenosis study. Circulation 2012; 125: 346-353.

21. Antonini-Canterin F, Huang G, Cervesato E, Faggiano P, Pavan D, Piazza R, Nicolosi GL. Symptomatic aortic stenosis: does systemic hypertension play an additional role? Hypertension 2003; 41: 1268-1272.

22. Briand M, Dumesnil JG, Kadem L, Tongue AG, Rieu R, Garcia D, Pibarot P. Reduced systemic arterial compliance impacts significantly on left ventricular afterload and function in aortic stenosis: implications for diagnosis and treatment. J Am Coll Cardiol 2005; 46: 291-298.

23. Chin CW, Djohan AH, Lang CC. The role of cardiac biochemical markers in aortic stenosis. Biomarkers 2016; 21: 316-327.

24. Kupari M, Turto H, Lommi J. Left ventricular hypertrophy in aortic valve stenosis: preventive or promotive of systolic dysfunction and heart failure? Eur Heart J 2005; 1790-1796.

25. Hachicha Z, Dumesnil JG, Bogaty P, Pibarot P. Paradoxical low-flow, low-gradient severe aortic stenosis despite preserved ejection fraction is associated with higher afterload and reduced survival. Circulation 2007; 115: 2856-64. 